\title{
Death and injury from motor vehicle crashes in Colombia
}

\author{
Jaime Posada, ${ }^{1}$ Eli Ben-Michael, ${ }^{2}$ Alan Herman, ${ }^{2}$ Ernesto Kahan, ${ }^{3}$ \\ and Elihu Richter ${ }^{2}$
}

ABSTRACT We report data on the distribution and determinants of road deaths and injuries for all victims in Colombia, with the aim of defining targets and priorities for highway death prevention in that country and other rapidly urbanizing nations. Using information from Colombia's Fund for the Prevention of Road Injury and the national death registry, we studied data on deaths and injuries from 1991 to 1995 for the nation as a whole and for the country's two largest cities, Santa Fe de Bogotá and Medellín. Deaths and injuries are rising in the nation as a whole. Of the deaths, $75 \%$ occur in urban areas, and $80 \%$ are in males. Pedestrians aged 15-34 are a peak subgroup. Thirty-four percent of deaths are attributable to speeding and/or alcohol consumption. Death tolls are highest at night and on weekends. Specific priority targets for intervention are indicated by the fact that $75 \%$ of road deaths in Colombia occur in urban areas and that $80 \%$ of all victims are males.

Colombia has a population of some 35 million people, approximately 120000 kilometers of roads, and around two million registered vehicles. Among males below age 35 in the country, motor vehicle injuries are the second ranking cause of death, after violence. Official sources for all motor vehicle crashes for 1995 reported 7874 dead and 52527 injured (Table 1) (1). The reported risk of death based on

\footnotetext{
Department of Research and Development of New Projects, Susalud EPS, Medellín, Colombia.

2 Betts Injury Prevention Project, Unit of Occupational and Environmental Medicine, Hebrew University-Hadassah School of Public Health and Community Medicine, Jerusalem, Israel. Address correspondence to: E. Richter, Unit of Occupational and Environmental Medicine, Hebrew University-Hadassah Medical School, POB 12272, Jerusalem 91120, Israel. Telephone: 972-2-6758147; fax: 972-2-6437219; e-mail: elir@cc.huji.ac.il

3 Department of Family Medicine, Rabin Medical Center, Beilinson Campus, Sackler Faculty of Medicine, Tel Aviv University, Tel Aviv, Israel.
}

kilometers traveled is 18 times the risk in the United States of America and 5 times that of Europe (2).

In 1993, the Government of Colombia instituted a mandatory vehicle insurance law for all licensed drivers and also standardized the road injury report system. Between 1991 and 1995, the number of reported deaths nearly doubled, the number of persons injured almost tripled (1), and there was a sharp rise in the number of insurance policy claims.

This paper is the first epidemiologic review of the distribution and determinants of road deaths and injuries in Colombia. We suggest that a relatively simple database for road deaths and injury trends in a developing country can be used to quickly define a staged, sequential strategy for prevention activities. The goal of this strategy is to achieve a large, swift drop in casualties using simple, cost-effective, sustain- able countermeasures in urban and interurban settings. We believe the case fatality rate is particularly useful in monitoring trends in crash speeds and in the effectiveness of speed control measures. The difficult problems Colombia has with violence, terrorism, and killings are well known, and they serve as a background for the findings and recommendations of this paper.

\section{METHODS}

We employed a descriptive method based on data from Colombia's Fund for the Prevention of Road Injury. The Fund receives police reports of motor vehicle accidents and casualties. In 1993, a National Insurance Law introduced a newly standardized reporting system that led to the increased reporting of less-severe vehicle crash injuries. In Colombia, a motor vehicle 
TABLE 1. Reported deaths and other injuries from motor vehicle crashes, Colombia, 1991-1995

\begin{tabular}{cccc}
\hline Year & Deaths & $\begin{array}{c}\text { Nondeath } \\
\text { injuries }\end{array}$ & CFR $^{\text {a }}$ \\
\hline 1991 & 4199 & 18182 & $18.8 \%$ \\
1992 & 4620 & 21280 & $17.8 \%$ \\
1993 & 5628 & 33083 & $14.5 \%$ \\
1994 & 6989 & 45940 & $13.2 \%$ \\
1995 & 7874 & 52527 & $13.0 \%$ \\
\hline
\end{tabular}

a CFR = case fatality rate (deaths as a proportion of both fatal and nonfatal injuries in crashes).

accident is defined as a crash or collision involving at least one motor vehicle and causing at least one injury or death to an occupant of the vehicle or to a pedestrian, within 30 days of the accident. Injuries are reported only if they involve hospitalization, but those reports often lack data on severity. Standardized injury severity scales are not yet in use. This paper reports data from 1991 through 1995.

Data on kilometers traveled in urban and interurban roads are reported by the Government of Colombia and are based on total annual fuel consumption, estimated fuel consumption for different types of vehicles, and periodic interurban monitoring of traffic volume. In the absence of a universally accepted definition of a road, for the purpose of this paper a road is defined as a surface, whether in an urban or rural environment, designated for the travel of vehicles. The classification of "urban roads" includes major highways and other types of roads within cities. "Rural roads" are all the roadways outside of urban areas.

\section{RESULTS}

\section{Nationwide trends in crashes, deaths, and injuries}

Reported motor vehicle crashes, deaths, and nondeath injuries rose steadily from 1991 through 1995 . From 1993 to 1995 , reported deaths rose from 5628 to 7874 , an increase of $40 \%$, and other reported injuries climbed from 33083 to 52527 , a rise of 59\% (Table 1). Over that same period, mortality rates per billion vehicle-kilometers traveled increased from 155.2 to 196.0, while the case fatality rate-deaths as a proportion of both fatal and nonfatal injuries in crashes-dropped from $14.5 \%$ to $13.0 \%$.

\section{Urban and rural trends}

Over the years 1991-1995, the overwhelming majority of the deaths occurred on urban roads (Table 2). For example, in $199575 \%$ of all the vehicle crash deaths happened in urban areas. There was a steady upward trend in reported urban deaths from 1991 to 1995 , from 3003 to 5903 , a rise of $96.5 \%$. In rural areas, death tolls also rose, from 1116 to 1971 , an increase of $76.6 \%$. During the years 1993 to 1995, the case fatality rate (CFR) dropped in urban areas from $14.7 \%$ to $12.3 \%$, but rose in rural areas from $14.0 \%$ to $16.0 \%$.

Colombia's two largest cities, Santa Fe de Bogotá and Medellín, showed trends similar to those for all of Colombia's urban areas. From 1991 to 1995, deaths rose from 1089 to 1387 in Bogotá and from 649 to 817 in Medellín despite a falling CFR in both cities (Table 3).

\section{Pedestrians}

In 1995, more than half of the victims nationwide were pedestrians (4 180 of

TABLE 2. Deaths and case fatality rates for roads in urban areas and rural areas of Colombia, 1991-1995

\begin{tabular}{|c|c|c|c|c|}
\hline \multirow[b]{2}{*}{ Year } & \multicolumn{2}{|c|}{ Urban areas } & \multicolumn{2}{|c|}{ Rural areas } \\
\hline & Deaths & $\mathrm{CFR}^{\mathrm{a}}$ & Deaths & CFR \\
\hline 1991 & 3003 & $21.6 \%$ & 1116 & $13.3 \%$ \\
\hline 1992 & 3330 & $19.8 \%$ & 1290 & $14.2 \%$ \\
\hline 1993 & 4220 & $14.7 \%$ & 1408 & $14.0 \%$ \\
\hline 1994 & 5204 & $12.5 \%$ & 1749 & $15.5 \%$ \\
\hline 1995 & 5903 & $12.3 \%$ & 1971 & $16.0 \%$ \\
\hline
\end{tabular}

TABLE 3. Reported deaths and other injuries from motor vehicle crashes, Bogotá and Medellín, Colombia, 1991-1995

\begin{tabular}{ccrr}
\hline City/Year & Deaths & $\begin{array}{c}\text { Other } \\
\text { injuries }\end{array}$ & CFR $^{\mathrm{a}}$ \\
\hline Bogotá & & & \\
1991 & 1089 & 4055 & $21.3 \%$ \\
1992 & 1284 & 5086 & $20.3 \%$ \\
1993 & 1261 & 11505 & $10.0 \%$ \\
1994 & 1341 & 13392 & $9.1 \%$ \\
1995 & 1387 & 15906 & $8.0 \%$ \\
Medellín & & & \\
1991 & 649 & 7291 & $8.3 \%$ \\
1992 & 664 & 9467 & $6.7 \%$ \\
1993 & 737 & 13202 & $5.3 \%$ \\
1994 & 719 & 17437 & $4.0 \%$ \\
1995 & 817 & 17149 & $4.6 \%$ \\
\hline
\end{tabular}

$\overline{{ }^{a} \text { CFR }=\text { case fatality rate (deaths as a proportion of both }}$ fatal and nonfatal injuries in crashes).

the 7874 deaths; $53 \%$ ). Of the pedestrian deaths in that year, 3991 (95.5\%) occurred in the cities. However, a higher proportion of pedestrians in cities survived after being hit that year; the reported CFR for pedestrians in rural areas was nearly double that in urban areas, $34 \%$ vs. $18 \%$.

\section{Deaths by gender and age}

In $1995,80 \%$ of the motor vehicle crash deaths involved males. More than half of the dead were under age 35: 1-14 years, 798 deaths (10\%); 15-34 years, 3552 deaths (45\%); 35-59 years, 2309 deaths (29\%); 60+ years, 1215 deaths (15\%). The CFR for those 60 and older, $27 \%$, was about twice as high as the rates for the other age groups, which ranged from $10 \%$ to $15 \%$.

\section{Deaths by time of day}

In 1995, while the number of kilometers traveled at night was reported to be one-fifth of that for daytime (3), 3937 of all reported deaths (50.0\%) and 21484 of all reported injuries (40.9\%) occurred at night. 
TABLE 4. Attributed causes of reported motor vehicle crashes, Colombia, 1995

\begin{tabular}{lcc}
\hline \multicolumn{1}{c}{ Attributed cause } & $\begin{array}{c}\text { Motor vehicle } \\
\text { crashes } \\
\text { (No.) }\end{array}$ & $\begin{array}{r}\text { Proportion of all crashes } \\
(\%)\end{array}$ \\
\hline High speed & 34166 & 19 \\
Driving under the influence of alcohol & 26973 & 15 \\
Poor driving skills & 12587 & 7 \\
Poor road conditions & 8991 & 5 \\
Driving out of lane & 5395 & 3 \\
Faulty brakes & 5395 & 3 \\
Passing on a curve & 3596 & 2 \\
No car lights & 3596 & 2 \\
Others: pedestrian lapses (not crossing & & 44 \\
where permitted, not observing traffic), & & 100 \\
adverse weather conditions, falling asleep & 79121 & 2 \\
at the wheel, etc. & 179820 & 2 \\
Total & & \\
\hline
\end{tabular}

\section{Driving too fast and under the influence of alcohol}

Table 4 shows that in 1995, 61139 of all the crashes and collisions (34\%) were attributable to speeding and/or driving under the influence of alcohol.

\section{DISCUSSION}

Case fatality rates from vehicle crashes in Colombia declined from $18.8 \%$ to $13.0 \%$ between 1991 and 1995 . Nevertheless, those rates were far above the levels of such countries as Israel $(1.1 \%-1.6 \%)(4)$ and the United States of America $(1.0 \%-1.1 \%)$ for the same period of time (1). It is almost certain that these much higher CFRs in Colombia can only be partially attributed to underreporting of less-severe injuries, especially after 1993, when the country's new insurance law mandated reporting as a condition for compensation.

The trends we report from Colombia draw attention to the rising tolls of dead and injured, especially among young men, from road crashes as motorization increases in rapidly growing third world cities. In Colombia, the target priorities for an intervention program are urban roadways and young men, given that the majority of the vehicle crash deaths in the country involve young drivers in cities. Furthermore, urban areas are easier to reach than remote rural areas and are therefore a more accessible target site for effective solutions at lower cost.

\section{Urban areas}

On urban streets with heavy pedestrian traffic, there is an urgent need to reduce vehicle travel speeds to 30 kilometers per hour (kph), the speed at which there is an abrupt increase in fatality risk for pedestrians struck by vehicles (4). Certain preventive measures have been shown to reduce deaths and injuries from road crashes by $50 \%$ to $80 \%$ and to be highly cost beneficial and cost effective (4). The use of roundabouts (small traffic circles) and road bumps can reduce speed; other environmental modifications can include bicycle paths, pedestrian crosswalks, and roadside speed cameras (5-10). Among other possible steps are improving high-risk points ("hot spots" or "black spots") so as to reduce road injuries, and adding more street lights, traffic lights, and reflectors on the midlines and sides of roads.

The inevitable increase in traffic congestion in urban areas is expected to lower average daytime speeds and CFRs. Nevertheless, it would be a mistake to rely on congestion alone as a

strategy for reducing the overall death toll.

\section{Drinking and driving}

Breath tests for drivers suspected of drunk driving are a priority need in Colombia. It is not unusual in either Bogotá or Medellín to find young men racing through the main thoroughfares at extremely high speeds under the influence of alcohol and other drugs. The problem of night drinking and driving affirms the case for limits on bar hours or bans on the nighttime sale of alcoholic beverages (11).

\section{Rural areas}

In rural areas in Colombia, death tolls and the CFR are steadily rising, probably the result of higher speeds on interurban roads, more truck travel, and a poorly developed emergency service system. Again, the use of electronic speed camera systems to enforce posted speed limits is suggested. Such systems have been shown to reduce speeds and deaths in rural areas by increasing detection levels to the point of deterrence (12). The camera systems can operate around-the-clock with limited manpower, and their evidence is irrefutable. Their impact can be monitored by watching trends in deaths and CFRs.

\section{CONCLUSIONS}

The medical community should take a role in educating policymakers and the public on the importance of these preventive measures, which can achieve far more than medical care alone. We suggest the use of the Haddon matrix to list and categorize strategies to prevent road injuries (13-15). The Haddon matrix is a simple grid that classifies interventions by category (human, vehicle, physical environment, socioeconomic environment) and stage (precrash, crash, postcrash).

The effectiveness of these prevention measures could be improved with 
further research on such issues as the impact that the economic and social environment and the instability endemic in Colombia have on young males and crashes; the need for new laws; and the availability of lifesaving emergency care. We also suggest that Colombia could help other countries in Latin America by sharing its experience in efforts to reduce motor vehicle deaths and injuries.

\section{REFERENCES}

1. Fund for the Prevention of Road Injury, National Insurance Fund for Colombia. Multiyear report on injuries and deaths from road accidents. Santa Fe de Bogotá: Fund for the Prevention of Road Injury; 1995.

2. International Road Federation. World Road Statistics-Standard Version, Volume 288. Geneva: International Road Federation; 1997.

3. Richter ED. Eradication of road death and serious injury: a perspective from environmental epidemiology. European Epi Marker, Newsletter of the International Center for Studies and Research in Biomedicine, January 1998.

4. Israel, Central Bureau of Statistics. Road accidents with casualties: part I. Jerusalem: Government of Israel; 1996. (Publication 1041).

5. Mulkhal N. Safety programs in a developing country: integrated approach and process evaluation. In: Proceedings of the Second International Conference on New Ways for Safety and Quality of Life. Tel Aviv: Israel Ministry of Transport; 1991.

6. Lourens PF. Young car drivers in The Hague: the prevention of bad driving habits after driving license has been obtained. In: Proceedings of the Second International Conference on New Ways for Safety and Quality of Life. Tel Aviv: Israel Ministry of Transport; 1991.

7. Van De Watering C. A traffic safety policy in the Netherlands. In: Proceedings of the Second International Conference on New Ways for Safety and Quality of Life. Tel Aviv: Israel Ministry of Transport; 1991.

8. Richter E. Prevention of death and injury from motor vehicle crashes in Israel: swift cost-effective options in the 1980s. Isr J Med Sci 1981;17:1175-1180.

9. Nelson DC, Struber JV. Fatality rates as a measure of accident activity in developing countries. In: Proceedings of the Second International Conference on New Ways for Safety and Quality of Life. Tel Aviv: Israel Ministry of Transport; 1991.

10. Proctor S. Planning road safety strategy at local level. In: Proceedings of the Fourth International Conference on Safety and the Environment. Tel Aviv: Israel Ministry of Transport; 1997.
11. Richter E, Meltzer U, Bloch B, Tyger G, BenDov R. Alcohol levels in drivers and pedestrians killed in road accidents in Israel. Int J Epidemiol 1986;15:272-273.

12. West R. The effect of speed cameras on injuries from road accidents. BMJ 1998;316 (7124):5-6.

13. Robertson LS. Injury epidemiology. New York: Oxford University Press; 1992. pp. 3-22.

14. Martinez R. Injury management and the emergency physician. Ann Emerg Med 1990; 19(1):97.

15. Hargarten SW. All-terrain vehicle mortality in Wisconsin: a case study in injury control. Am J Emerg Med 1991;9(2):149-152.

Manuscript received on 23 March 1999. Revised version accepted for publication on 12 December 1999.

RESUMEN Con el fin de definir objetivos y prioridades para la prevención de las muertes en carretera en Colombia y en otros países que se encuentran en rápido proceso de urbanización, presentamos datos sobre la distribución y determinantes de las muertes y lesiones por accidentes de tráfico en Colombia. Utilizando información del Fondo de Prevención Vial Nacional y del registro nacional de defunciones, estudiamos los datos correspondientes al período comprendido entre 1991 y 1995, tanto en la totalidad del país como en sus dos principales ciudades: Santa Fe de Bogotá y Medellín. En el ámbito nacional, las muertes y lesiones por esta causa están en aumento. En relación con las muertes, $75 \%$ ocurrieron en áreas urbanas y $80 \%$ de las víctimas fueron varones, cifras que señalan la existencia de objetivos prioritarios específicos para la intervención. El subgrupo más afectado fue el de los peatones de 15 a 34 años de edad. Treinta y cuatro porciento de las muertes fueron atribuibles a exceso de velocidad o consumo de alcohol. El número de víctimas mortales fue más elevado por las noches y en los fines de semana. 